\title{
What explains the technical efficiency of banks in Tunisia? Evidence from a two-stage data envelopment analysis
}

\author{
Mohamed Mehdi Jelassi ${ }^{*}$ (D) and Ezzeddine Delhoumi
}

\section{${ }^{*}$ Correspondence:}

mehdi.jelassi@gmail.com IHEC Carthage and LEFA,

Carthage University,

Rue Victor Hugo,

2016 Carthage Présidence, Tunisia

\begin{abstract}
In this study we examine the potential determinants of technical efficiency for the Tunisian commercial banking sector over the period of 1995-2017. First, we estimate banking technical efficiency with a radial and non-radial bootstrap data envelopment analysis. For the radial technique, we use an input-oriented approach and for non-radial we use the Range Adjusted Measure (RAM). Second, we use a double bootstrapping regression technique to estimate the influence of a set of eventual determinants on technical efficiency. Finally, based on all possible regressions, we gauge the overall effect of each determinant. Our results reveal that the input-oriented and RAM approach gave somewhat similar results. We found that the return on equity, the expense to income ratio, the loan to deposit ratio, and the growth rate are insignificant to Tunisian banking technical efficiency. In particular, banking technical efficiency increases with capitalization and inflation, whereas, it decreases with size, number of bank branches, management to staff ratio, and loan to asset ratio. In addition, we identified evidence supporting the moderate success of the last decade of reforms and a noticeable one for the post-revolution reforms in helping improve banking technical efficiency. The post-revolution reforms, largely revolving around reinforcing the rules of good governance and banking supervision, coupled with the restructuring of public banks, were found to be insufficient to raise overall banking technical efficiency despite improvement in the technical efficiency of private banks.
\end{abstract}

Keywords: Tunisian banks, Financial intermediation, Technical efficiency, Data envelopment analysis, Bootstrap, Bias correction, Truncated regression

JEL Classification: G21, C61, C24, C14

\section{Introduction}

The banking sector in Tunisia has long been considered a cornerstone of the country's development process. It has acted as the principal financial intermediary by reallocating collected funds to meet investment and consumption demands. From 1995 to 2017, deposit money banks provided, on average, $81 \%$ of all domestic credits demanded by the private sector. In particular, from 2011 to 2017, the domestic credit provided by banks to the private sector has been steadily increasing, representing, on average, $63 \%$ of Tunisia's Gross Domestic Product (GDP), and reaching as high as 69\% of GDP in 2017. Despite

c) The Author(s), 2021. Open Access This article is licensed under a Creative Commons Attribution 4.0 International License, which permits use, sharing, adaptation, distribution and reproduction in any medium or format, as long as you give appropriate credit to the original author(s) and the source, provide a link to the Creative Commons licence, and indicate if changes were made. The images or other third party material in this article are included in the article's Creative Commons licence, unless indicated otherwise in a credit line to the material. If material is not included in the article's Creative Commons licence and your intended use is not permitted by statutory regulation or exceeds the permitted use, you will need to obtain permission directly from the copyright holder. To view a copy of this licence, visit http:// creativecommons.org/licenses/by/4.0/. 
such a crucial role played by banks to channel funds to the economy, the government did not cease from calling on banks to improve their efficiency. In fact, banking efficiency was recognized as the main actor in the overall financial development of any emerging economy (Andersen and Tarp 2003; Chan and Karim 2010).

Starting from the 1990s, Tunisia's willingness to integrate into the world economy urged the government to launch several economic and financial reform programs. Vast restructuring programs revolving around the deregulation and modernization of the banking sector were initiated as a key pillar to the government's development plan. The Tunisian government's unceasing efforts to amend banking operational efficiency can be deduced from the various regulations instituted over the last three decades. In fact, three main influential interventions by the Tunisian central bank, which undoubtedly shaped the technical efficiency of Tunisian banks, can be distinguished. The first is circular No. 91-24, issued in 1991 regarding credit classification and provisioning. Second, the promulgation of law No. 2001-65 in 2001, listing and defining the banking operations of credit institutions and reinforcing it in 2006 by circular No. 2006-06, implementing an internal conformity system. Third, releasing circular No. 2011-06 in 2011 to reinforce the rules of good governance within credit institutions. Hence, banks were continuously exhorted to establish a healthy and prudent management by keeping track of their own performance and working on improving their managerial operations.

However, how efficiently were banks actually operating in Tunisia? Did their technical efficiency improve over time in accordance with the central authority's objectives? Were private banks more technically efficient than their public counterparts? Did the recent ongoing changes in the political system affect bank efficiency? What are the main determinants of the banks' technical efficiency? Such questions are worth studying not only for Tunisia but for any country. In particular, as noted by Berger and Humphrey (1997), investigating banking efficiency can bring about many insights to decisionmakers and policymakers. Not only can the evolution of technical efficiency detect the impact of reforms on bank's organizational performance, but the determinants of technical efficiency can also help in designing banking regulations to enhance banking performance.

Numerous studies employ the Data Envelopment Analysis (DEA) technique, and a second stage regression to explain the technical efficiency of banks in some emerging economies. Among such studies are Sufian (2009) and Saha et al. (2015) for Malaysia, Sufian and Habibullah (2010) for Thailand, Ben Naceur et al. (2011) for the Middle East and North African (MENA) countries (including Tunisia), Ayadi (2014) for Tunisia, Repkova (2015) for the Czech Republic, Tan (2016) for China, Shazida Jan et al. (2017) for various Southeast Asian countries, Batir et al. (2017) for Turkey, Tadesse (2017) for Ethiopia, Banya and Biekpe (2018) for ten African countries including Tunisia, Banna et al. (2019) for East Asian countries, and Jiménez-Hernández et al. (2019) for Latin American countries. The determinants considered in these studies differed according to the study's purpose, and the findings varied from one country to another.

Most of the studies employed an input-oriented approach to estimate technical efficiency, claiming that bank managers tend to control inputs more than outputs. Nevertheless, managers are more likely to be confronted with the objective of minimizing the quantity of resources used and asked to produce the maximum outputs possible. In order to allow for such practical considerations and further examine the robustness of 
the estimated efficiency scores, the present study estimates technical efficiency according to both the input-oriented and Range Adjusted Measure (RAM) approaches. In the case of Tunisia, since banks are far from realizing economies of scale (World Bank 2014b), estimates for technical efficiency are obtained under the assumption of variable returns to scale (VRS).

In addition to the fact that the Tunisian case has not been studied extensively, we provide an analysis for the largest time period ever examined in the literature. Our sample period spans 23 years, from 1995 to 2017. First, since our sample covers a relatively long period, both the amounts of inputs and outputs could be adjusted by managers, justifying the RAM approach. Second, substantial technical progress in the banking industry has certainly occurred overall: to address this problem, time is included as an explanatory variable in the second stage regression of technical efficiency, along with other explanatory variables. During the sample period, Tunisia also experienced the 2011 social uprising which led to the ending of an authoritarian regime and the implementation of a democratic one. Thus, the effect of the 2011 revolution on the technical efficiency of Tunisian banks, as well as their ownership structure, was also analyzed.

This paper proceeds as follows: the following section introduces Tunisia and its need for an efficient banking sector. Section Literature review presents the literature review on the determinants of technical efficiency of banks in some emerging economies. Section Methodology and data provides the methodologies and data used to estimate the technical efficiency of Tunisian banks. Section Results and discussion presents the results and discussion and Sect. Conclusions concludes.

\section{Tunisia and its need for an efficient banking sector}

Tunisia is a small, open economy in transition, situated in the MENA region and classified by the World Bank as a lower middle-income economy. During the last few decades, Tunisia has relied on an export-led growth model enhanced by innovation (World Bank 2010). Despite having signed a number of agreements with several countries, including its neighboring Arab and Sub Saharan African countries, Tunisia's most significant economic bloc has always been the European Union (EU). Being geographically close to Europe and having historical ties with France enhanced Tunisia's integration into the European single market. Tunisia is building on its existing free trade area with the EU for industrial and manufactured goods to create a Deep and Comprehensive Free Trade Area (DCFTA) (Tröster et al. 2018).

Despite its small size and marginal role in the politics of the Arab world, Tunisia has attracted considerable global attention by leading the region in implementing reforms and influencing political and economic developments across the region (Teti et al. 2018). It is even considered by the World Bank as an important example from which interesting lessons can be learned (World Bank 2014a).

For its development process, Tunisia has been financially and technically assisted by the EU and many international organizations. Beyond trade facilitation and the upgrading of the manufacturing sector, Tunisian authorities have strongly believed that such reforms must be accompanied by an efficient banking sector. Consequently, close cooperation with the World Bank and the International Monetary Fund (IMF) was set. The ongoing close collaboration with the IMF, which includes promoting financial 
intermediation among others (IMF 2016) is challenging the economic, political, and social circumstances as a result of the 2011 social revolution. In fact, apart from bringing an authoritarian political regime to an end and succeeding in putting the country on a democratic transition, the revolution did not meet its economic expectations (Teti et al. 2018). Prior to the revolution, the banking sector has been used as a tool for privileged access to finance. In particular, state-owned banks were used to provide funds to cronies and state-owned enterprises at convenient rates and low collaterals with no regard to risk management (World Bank 2014b). Thereby, in addition to not helping to reduce the rate of non-performing loans, the technical efficiency of the banking sector was deeply distorted. Immediately following the 2011 revolution, the economy was adversely impacted through the investment channel (Matta et al. 2019) and hence, banking technical efficiency was most likely condemned to deteriorate. However, the recapitalization of the three state-owned banks initiated in 2012, and their ongoing restructuring process, certainly helped improve their banking operations efficiency. Moreover, the recent ongoing reforms revolving around strengthening banking supervision and increasing access to finance (IMF 2016), certainly helped improve the technical efficiency of the whole banking sector.

\section{Literature review}

Investigating the determinants of the technical efficiency of banks in emerging economies using the DEA technique has gained considerable attention. The existing literature can be classified into two broad groups: those that deal with a group of similar countries and those that focus on the banking sector of a specific country. In the first group of cross-country bank efficiency studies, Ben Naceur et al. (2011) investigated the effect of several determinants of performance and efficiency for banks in five MENA countries, including Tunisia, over the period of 1994-2008. More recently, Shazida Jan et al. (2017) evaluated bank efficiency across a number of Southeast Asian countries over the period of 1998-2012. Banya and Biekpe (2018) studied the determinants of bank efficiency for ten African countries, including Tunisia, over the period of 2008-2012. Banna et al. (2019) investigated the determinants of bank efficiency across East Asian countries over the period of 2000-2013. Jiménez-Hernández et al. (2019) analyzed internal and external factors that may explain the difference in technical efficiency for 17 Latin American countries over the period of 2014-2016.

In the second group of studies that focused on a single emerging country, Sufian (2009) estimated the technical efficiency of Malaysian banks over the period of 1995-1999. In a more recent study, Saha et al. (2015) also investigated the determinants of technical efficiency of Malaysian banks over the period of 2005-2012. Sufian and Habibullah (2010) examined the determinants of banking efficiency in Thailand over the period of 19992008. Repkova (2015) studied the determinants of commercial banking efficiency for the Czech Republic during the period of 2001-2012. Tan (2016) investigated the effect of risk conditions, some bank-specific variables, industry-specific variables, and some macroeconomic variables on the efficiency of Chinese commercial banks over the period of 2003-2013. Batir et al. (2017) analyzed the internal and external determinants of participation and conventional banking efficiency in Turkey over the period of 2005-2013. 
Tadesse (2017) studied the determinants of technical efficiency for commercial banks in Ethiopia over the period of 2011-2014.

The existing literature investigated various determinants of technical efficiency depending on the purpose and nature of the study. However, a closer look at these determinants reveals that the main bank-specific factors that were examined are capitalization or leverage, bank size, profitability, loan intensity, liquidity risk, and credit risk, whereas, the main country-specific factors that were examined included economic growth, inflation, and interest rate.

Apart from the positive impact of loan intensity on technical efficiency, the negative effect of interest rates on technical efficiency, and the negative relationship of nonperforming loans with technical efficiency, mixed results were reported for the other variables. More precisely, Sufian (2009), Saha et al. (2015), Banna et al. (2019) and Jiménez-Hernández et al. (2019) found that bank size is significantly and positively related with technical efficiency. However, Batir et al. (2017) found a negative relationship between bank size and technical efficiency. Repkova (2015) and Banya and Biekpe (2018) on the other hand, found that bank size is insignificant to technical efficiency. Capitalization was found to be positively related to technical efficiency by most of the studies, except Batir et al. (2017) who found a negative relationship between capitalization and technical efficiency. Profitability was found to be positively related to technical efficiency by most studies, except Repkova (2015) who found that profitability was negatively related to technical efficiency. Liquidity risk was found to be positively related to technical efficiency by most studies, except Banya and Biekpe (2018) who found that liquidity risk is non-significant to technical efficiency. Credit risk was found to be ambiguous. Sufian and Habibullah (2010) found that credit risk was negatively related to technical efficiency. Whereas, Banya and Biekpe (2018) found that risk was positively related to technical efficiency. Economic growth was found to be negatively related to technical efficiency, except for Banna et al. (2019) and Tan (2016) who both found a positive relationship between economic growth and technical efficiency. Inflation was found to be negatively related to technical efficiency by most of the studies, except for Tan (2016) who found that inflation had a positive impact on technical efficiency.

Despite growing literature on the different determinants of technical efficiency of banks for developing countries, the case of Tunisia has rarely been studied separately. Ayadi (2014) examined the determinants of technical efficiency for Tunisian banks over the period of 2000-2011. Only four bank-specific variables were examined: size, capitalization, market share (deposits), and ownership. Ayadi (2014) found that size was not significant in explaining technical efficiency. Capitalization was found to be positively related to technical efficiency while deposits (market share) were negatively related to technical efficiency. She also found that private banks were technically more efficient than public ones.

Most of the studies that employed DEA, used an input-oriented approach. In the input-oriented approach, a bank is treated as a decision unit whose efficiency is measured by its relative ability to produce a given amount of outputs by seeking proportional possible reductions in inputs. The usage of the input-oriented approach to measure bank efficiency is justified by the fact that banks could have more control on costs rather than output. Nevertheless, banks can be treated as having control over both inputs and 
outputs. Consequently, the efficiency of a bank can also be measured by its ability to simultaneously minimize inputs and maximize outputs. Thus, a bank is deemed fully efficient if and only if it is Pareto efficient. In order to achieve this, we applied Cooper et al's (1999) RAM model to the case of Tunisian banks.

\section{Methodology and data}

Technical efficiency can be measured by radial or non-radial DEA techniques. In this study we use the radial model, the input-oriented model, and a non-radial model which is the RAM. Both approaches are applied under the VRS condition in order to allow banks to operate at a different scale than their optimal one. According to the input-oriented approach, the efficient bank is the one that minimizes inputs to produce a certain amount of outputs. Hence, under the VRS condition, the estimation of the technical efficiency level $\left(T E_{i n p, k \tau}\right)$ of a bank $k=1, \ldots, n$ at period $\tau=1, \ldots, T$ is determined by the following DEA model:

$$
\begin{aligned}
& T E_{i n p, k \tau}=\operatorname{Min}_{k \tau} \\
& \text { st. } \\
& \sum_{t=1}^{T} \sum_{j=1}^{n} \lambda_{j t} x_{i j t} \leq \theta_{k \tau} x_{i k \tau}, \quad i=1, \ldots, m \\
& \sum_{t=1}^{T} \sum_{j=1}^{n} \lambda_{j t} y_{r j t} \geq y_{r k \tau}, \quad r=1, \ldots, s \\
& \sum_{t=1}^{T} \sum_{j=1}^{n} \lambda_{j t}=1 \\
& \lambda_{j t} \geq 0, \quad j=1, \ldots, n \text { and } \quad t=1, \ldots, T \\
& \theta_{k \tau} \text { unrestricted }
\end{aligned}
$$

In the radial models, restricting attention to a particular orientation can neglect the major source of inefficiency in another direction (Berger et al. 1993). The RAM model allows for the capture of potential non-radial changes in inputs and outputs we would expect in practice. Avkiran and Morita (2010) and Tone and Tsutsui (2010) argue that estimating non-proportional projections through non-radial models is a more realistic representation of a complex business world. Moreover, the translation invariance as well as unit invariance properties of the RAM model are of particular significance in a business environment where negative numbers are part of the performance measurement and data transformation is used (Avkiran and McCrystal 2014). In fact, unlike the radial models, the RAM model has the advantage of directly handling the occurrence of zero or negative values in the input-output data set. It was exploited to analyze context-dependent bank efficiency measures. For instance, Chang (2013) estimated the profitability and marketability efficiencies and multi-component efficiency of Taiwan's banking industry based on RAM and RAM variation models. Chiu et al. (2014) also explored the operational performance of commercial banks in Taiwan using different evaluative contextdependent RAM models, taking into consideration negative and undesirable outputs. 
According to the RAM approach, the efficient bank is the one that simultaneously maximizes outputs and minimizes inputs. The goal vector approach of Thrall (1996), which is basically designed for cross section estimates, is applied to the panel of Tunisian commercial banks. Hence, the technical efficiency $\Gamma_{k \tau}$ of each bank $k$ in each year $\tau$ is given by,

$$
\Gamma_{k \tau}=1-\frac{1}{(m+s)} Z_{k \tau}
$$

where $m$ and $s$ are the number of inputs and outputs, respectively, and $Z_{k \tau}$ is the value of the following optimization problem of each bank $k(k=1, \ldots, n)$ in each period $\tau$ $(\tau=1, \ldots, T)$ :

$$
\max _{\lambda_{j t}, s_{i k \tau}^{-} s_{r k \tau}^{+}} Z_{k \tau}=\sum_{i=1}^{m} g_{i}^{-} s_{i k \tau}^{-}+\sum_{r=1}^{s} g_{r}^{+} s_{r k \tau}^{+}
$$

st.

$$
\begin{aligned}
& \sum_{t=1}^{T} \sum_{j=1}^{n} x_{i j t} \lambda_{j t}+s_{i k \tau}^{-}=x_{i k \tau}, \quad i=1, \ldots, m \\
& \sum_{t=1}^{T} \sum_{j=1}^{n} y_{r j t} \lambda_{j t}-s_{r k \tau}^{+}=y_{r k \tau}, \quad r=1, \ldots, s \\
& \sum_{\mathrm{t}=1}^{T} \sum_{j=1}^{n} \lambda_{j t}=1, \\
& \lambda_{j t} \geq 0, \quad j=1, \ldots, n, \quad t=1, \ldots, T \\
& s_{i k \tau}^{-} \geq 0, \quad i=1, \ldots, m \\
& s_{r k \tau}^{+} \geq 0, \quad r=1, \ldots, s
\end{aligned}
$$

where $x_{i j t}$ is the quantity of input $i(i=1, \ldots, m)$, used by bank $j(j=1, \ldots, n)$, in period $t(t=1, \ldots, T) . \quad y_{r j t}$ is the quantity of output $r(r=1, \ldots, s)$, produced by bank $j(j=1, \ldots, n)$, in period $t(t=1, \ldots, T) . s_{i k \tau}^{-}$is the over utilization of input $i$ by bank $k$ in period $\tau . s_{r k \tau}^{+}$is the under production of output $r$ by bank $k$ in period $\tau . g_{i}^{-}$and $g_{r}^{+}$are weights of the slack variable to input $i$, and that to output $r$, respectively.

Following Cooper et al. (1999), we set $g_{i}^{-}=\frac{1}{R_{i}^{-}}$and $g_{r}^{+}=\frac{1}{R_{r}^{+}}$, where $R_{i}^{-}=\max _{t j} x_{i j t}-\min _{t j} x_{i j t}$ is the range of input $i$, and $R_{r}^{+}=\max _{t j} y_{r j t}-\min _{t j} y_{r j t}$ is the range of output $r$.

Now, bank $k$ at time $\tau$ is said to be efficient if and only if all slacks are null. The technical efficiency measure $\Gamma_{k \tau}$, takes values between 0 and 1 , with higher values indicating increasing efficiency. More precisely, as claimed in Cooper et al. (1999), the following six properties should hold:

1. $0 \leq \Gamma_{k \tau} \leq 1$

2. $\Gamma_{k \tau}=\left\{\begin{array}{l}1 \Leftrightarrow \text { bank is fully Pareto }- \text { Koopmans efficient } \\ 0 \Leftrightarrow \text { bank is fully inefficient }\end{array}\right.$

3. $\Gamma_{k \tau}$ is invariant to alternative optima and of alternative units.

4. $\Gamma_{k \tau}$ is strongly monotonic with respect to input and output slacks (to inefficiencies). 
Table 1 Efficiency contribution measures for the DEA model variables

\begin{tabular}{lll}
\hline Variable & \multicolumn{2}{l}{$\begin{array}{l}\text { Proportion, in \%, of bank-year observations } \\
\text { with } E C M>\mathbf{1 . 1}\end{array}$} \\
\cline { 2 - 3 } & Input-oriented & Output-oriented \\
\hline Labor, $x_{1}$ & 27.9 & 23.2 \\
Physical capital, $x_{2}$ & 16.6 & 16.2 \\
Financial capital (deposits), $x_{3}$ & 50.5 & 68.4 \\
Bank's portfolio, $y_{1}$ & 15.3 & 17.1 \\
Loans, $y_{2}$ & 44.9 & 55.3 \\
Interbank loans, $y_{3}$ & 20.5 & 28.4 \\
Off-balance sheet commitments, $y_{4}$ & 14.5 & 16.6 \\
\hline
\end{tabular}

5. $\Gamma_{k \tau}$ is invariant to translation (but only in VRS technology).

6. $\Gamma_{k \tau}$ provides a consistent ranking of banks in terms of inefficiency.

As of 2017, the Tunisian banking sector was composed of 30 banks, 23 of which are onshore banks and seven are offshore banks (CBT 2017). Among the 23 onshore banks, 20 are conventional commercial banks and three are specialized in Islamic banking (5.1\% total banking assets). There are six publicly-owned conventional commercial banks, two of which are specialized in financing micro projects and small and medium sized enterprises (SMEs). The three largest publicly-owned conventional commercial banks are the National Agricultural Bank (NAB), Tunisian Banking Company (TBC), and the Bank of Housing (BH). According to figures from the Tunisian Professional Association of Banks and Financial Institutions (TPABFI), during the period of 2011 to 2017, these three banks owned on average $24.8 \%$ of total bank branches and employed $33.1 \%$ of total banking staff. They accounted a yearly average of $32.5 \%$ of total banking assets, generated $29.2 \%$ of total gross banking income, provided $34.6 \%$ of total loans by banks, and collected $32.2 \%$ of total deposits in banks.

Our sample includes the three largest publicly-owned conventional banks and the seven largest private ones. Collectively, these 10 banks possessed over the period of 2011 to 2017 , on average, $85.9 \%$ of total bank branches and employed $83.4 \%$ of total banking staff. During the same period, they accounted an annual average of $87.3 \%$ of total banking assets, generated $89.2 \%$ of total gross banking income, provided $88.7 \%$ of total loans by banks, and collected $90.2 \%$ of total deposits in banks.

Sufian (2009) presents the different alternatives used to model the role played by banks. The intermediation approach, as introduced in Sealey and Lindley (1977), suits the Tunisian case well since banks are mainly collecting savings from the economy to finance investment and consumption needs. Hence, for our study, labor, $x_{1}$, physical capital, $x_{2}$, and financial capital (deposits), $x_{3}$, are used by banks as inputs to produce the bank's portfolio, $y_{1}$, loans, $y_{2}$, interbank loans, $y_{3}$, and off-balance sheet commitments, $y_{4}$.

The selected three-input/four-output DEA model is indeed validated by the Efficiency Contribution Measure (ECM) proposed by Pastor et al. (2002). In our case, following Nataraja and Johnson (2011) and as recommended in Pastor et al. (2002), a candidate variable is deemed relevant to the DEA model if more than $15 \%$ of bank-year 
Table 2 Descriptive statistics for the variables in the DEA models

\begin{tabular}{|c|c|c|c|c|c|}
\hline & Obs & Min & Max & Average & Std. err \\
\hline \multicolumn{6}{|l|}{ Input variable } \\
\hline Labor, $x_{1}$ & 230 & 693 & 3,154 & 1,619 & 697 \\
\hline Physical capital, $x_{2}$ & 230 & 8,336 & 220,078 & 58,883 & 41,046 \\
\hline Financial capital (deposits), $x_{3}$ & 230 & 362,887 & $10,585,228$ & $2,570,268$ & $1,857,152$ \\
\hline \multicolumn{6}{|l|}{ Output variable } \\
\hline Bank's portfolio, $y_{1}$ & 230 & 11,144 & $1,947,637$ & 417,482 & 428,429 \\
\hline Loans, $y_{2}$ & 230 & 402,348 & $9,393,664$ & $2,608,455$ & $1,848,771$ \\
\hline Interbank loans, $y_{3}$ & 230 & 38,479 & $1,733,488$ & 358,776 & 317,235 \\
\hline Off-balance sheet commitment, $y_{4}$ & 230 & 0 & $6,824,186$ & $1,794,633$ & $1,268,340$ \\
\hline
\end{tabular}

Nominal values are reported in thousand Tunisian dinars

observations have their technical efficiency changed by at least 10\%. Table 1 displays the calculated ECM for each variable based on the input- and output-oriented approaches.

The input and output variables are obtained from the published balance sheets and income statements of each bank in annual reports released by the TPABFI. Our sample consists of a panel of 10 banks with 230 bank-year observations. Hence, the condition of $n \geq \max \{m s, 3(m+s)\}$, where $n$ is the number of decision-making units (DMUs), $m$ is the number of inputs, and $s$ is the number of outputs (given in Cooper et al. 2007) is verified.

The descriptive statistics for the input and output variables used in the DEA models are given in Table 2 . The role played by Tunisian banks, as an intermediary between savers and borrowers is clearly reflected by the sample averages given in Table 2 .

Since technical efficiency estimates take values between 0 and 1, many studies, such as Sufian (2009), Garza-Garcia (2012), Tadesse (2017), and Banna et al. (2019) used the censored Tobit model to identify the determinants of technical efficiency that were estimated separately in a first stage analysis. Other studies, such as Ben Romdhane (2013) and Tasnim and Afzal (2018) claim that technical inefficiency rather than technical efficiency should be regressed against its determinants. However, that does not give different estimates. Simar and Wilson (2011) and Daraio et al. (2018) showed that such studies that simply regressed the obtained DEA estimates in a first stage against their determinants is misspecified, hence, producing biased parameter estimates and leading to questionable inferences. More precisely, such a two-stage estimation erroneously imposes a strong assumption, known as the separability condition, which states that the explanatory variables used in the second stage to explain inefficiency cannot influence the technology frontier ( $\mathrm{Du}$ et al. 2018). In order to overcome this, we used Simar and Wilson's (2007) double bootstrapping technique to obtain consistent estimates for the model parameters of the potential determinants of banking technical efficiency. Our bootstrap truncated regression consists of regressing technical efficiency against a set of bank-specific characteristics and some economic variables. This can be described by the following model: 
Table 3 Descriptive of the variables used in the truncated regressions

\begin{tabular}{|c|c|c|c|}
\hline \multicolumn{2}{|l|}{ Bank specific factors } & \multirow{2}{*}{$\begin{array}{l}\text { Description } \\
\text { Public or private }\end{array}$} & \multirow{2}{*}{$\begin{array}{l}\begin{array}{l}\text { Expected } \\
\text { relationship }\end{array} \\
+/-\end{array}$} \\
\hline Ownership & Ownership & & \\
\hline Bank size & Size & Total assets & + \\
\hline \multicolumn{4}{|l|}{ Organizational variables } \\
\hline Number of branches & N_B & & $+/-$ \\
\hline Management to staff ratio & Staffing & Number of executives over total number of employees & $+/-$ \\
\hline \multicolumn{4}{|l|}{ Profitability } \\
\hline Return on assets & $\mathrm{ROA}$ & Net income over total assets & + \\
\hline Return on equity & ROE & Net income over equity & + \\
\hline Expense to income ratio & EIR & Total banking expenses over gross banking income & - \\
\hline \multicolumn{4}{|l|}{ Liquidity risk } \\
\hline Loan to deposit ratio & LDR & Total loans over total deposits & + \\
\hline \multicolumn{4}{|l|}{ Loans intensity } \\
\hline Loan to asset ratio & LAR & Total loans over total assets & + \\
\hline \multicolumn{4}{|l|}{ Capitalization } \\
\hline Capital to asset ratio & CAR & Total equity over total assets & + \\
\hline \multicolumn{4}{|l|}{ Macroeconomic variables } \\
\hline Inflation rate & Inflation & & - \\
\hline Real growth rate & Growth & & $+/-$ \\
\hline
\end{tabular}

$$
T E_{i t}=\alpha_{0}+\sum_{j=1}^{p} \alpha_{j} x_{i t}^{j}+\sum_{k=1}^{q} \alpha_{p+k} y_{t}^{k}+\varepsilon_{i t}
$$

where $T E_{i t}$ is the technical efficiency of the $i$ th bank in period $t . x_{i t}^{j}$, is characteristic $j$ $(j=1, \ldots, p)$ of bank $i$ at period $t . y_{t}^{k}$ is the economic variable $k(k=1, \ldots, q)$ at period $t . \varepsilon_{i t}$ is a random disturbance.

We went over the annual reports published by TPABFI and collected the data needed to determine as many series of bank-specific variables as possible. The obtained set of bank characteristics includes bank size, number of branches, management to staff ratio, return on assets, return on equity, expense to income ratio, loan to deposit ratio, loan to asset ratio and capital to asset ratio. Whereas, the economic variables which were obtained from the World Bank database include the inflation rate and real growth rate.

The independent variables used in the truncated regression models, their notations, descriptions, and the expected signs of their relationship with technical efficiency are summarized and given in Table 3.

\section{Results and discussion}

We combined the input-oriented and RAM models under the VRS assumption with the bootstrapping technique, analogous to Simar and Wilson (2000), and obtained estimates of technical efficiencies, their biases, standard deviations, and 95\% confidence intervals. The period average values of the latter measures are given in Table 4 . The small values obtained for the biases, standard deviations, and the small ranges of confidence intervals demonstrate that the obtained bias-corrected estimates are very robust, and our data set is homogenous. 
Table 4 Period averages of original and bias-corrected technical efficiency measures

\begin{tabular}{|c|c|c|c|c|c|c|c|c|c|c|c|c|}
\hline \multirow[t]{2}{*}{ Year } & \multicolumn{6}{|c|}{ Input-oriented } & \multicolumn{6}{|l|}{ RAM } \\
\hline & $\mathrm{TE}$ & Bias & BC_TE & Std & Low & Up & $\mathrm{TE}$ & Bias & BC_TE & Std & Low & Up \\
\hline 1995 & 96.0 & 8.4 & 87.6 & 6.2 & 75.3 & 95.3 & 98.8 & -0.3 & 99.1 & 1.9 & 95.7 & 103.8 \\
\hline 1996 & 94.0 & 6.3 & 87.7 & 4.7 & 77.7 & 93.4 & 98.0 & -0.5 & 98.5 & 1.9 & 95.3 & 102.4 \\
\hline 1997 & 89.2 & 5.0 & 84.2 & 3.4 & 76.2 & 88.6 & 95.0 & 0.7 & 94.3 & 1.3 & 92.2 & 97.5 \\
\hline 1998 & 89.1 & 4.5 & 84.6 & 3.1 & 77.8 & 88.5 & 94.8 & 1.0 & 93.8 & 1.5 & 91.0 & 97.6 \\
\hline 1999 & 89.3 & 5.0 & 84.3 & 3.7 & 76.6 & 88.7 & 93.8 & 1.3 & 92.5 & 1.4 & 90.0 & 95.7 \\
\hline 2000 & 89.7 & 4.1 & 85.6 & 2.4 & 80.4 & 89.1 & 94.7 & 0.4 & 94.3 & 1.6 & 91.2 & 97.8 \\
\hline 2001 & 89.3 & 3.7 & 85.5 & 1.9 & 81.9 & 88.7 & 92.8 & 1.7 & 91.1 & 1.3 & 88.9 & 94.6 \\
\hline 2002 & 88.7 & 3.0 & 85.6 & 1.6 & 82.4 & 88.1 & 92.8 & 2.5 & 90.2 & 1.9 & 86.8 & 94.3 \\
\hline 2003 & 85.9 & 3.2 & 82.8 & 1.6 & 79.7 & 85.4 & 91.7 & 2.4 & 89.3 & 1.1 & 87.3 & 91.6 \\
\hline 2004 & 84.9 & 3.1 & 81.8 & 1.5 & 78.8 & 84.3 & 90.9 & 1.9 & 89.0 & 1.0 & 87.0 & 91.5 \\
\hline 2005 & 83.4 & 2.9 & 80.5 & 1.4 & 77.8 & 82.8 & 90.4 & 1.7 & 88.7 & 1.0 & 86.8 & 91.0 \\
\hline 2006 & 83.8 & 2.9 & 80.9 & 1.4 & 78.3 & 83.3 & 90.2 & 1.6 & 88.6 & 1.1 & 86.7 & 91.1 \\
\hline 2007 & 85.4 & 3.5 & 81.9 & 2.0 & 77.8 & 84.8 & 90.9 & 2.0 & 88.8 & 1.5 & 85.7 & 91.7 \\
\hline 2008 & 87.4 & 4.7 & 82.8 & 3.2 & 75.9 & 86.9 & 91.7 & 2.3 & 89.4 & 2.2 & 85.7 & 94.5 \\
\hline 2009 & 88.4 & 5.0 & 83.4 & 3.8 & 74.5 & 87.8 & 91.3 & 2.3 & 89.1 & 2.4 & 84.9 & 94.0 \\
\hline 2010 & 90.1 & 3.7 & 86.5 & 2.3 & 81.0 & 89.5 & 91.6 & 2.3 & 89.4 & 2.3 & 85.2 & 93.5 \\
\hline 2011 & 91.1 & 4.0 & 87.1 & 2.4 & 82.3 & 90.5 & 91.0 & 2.3 & 88.7 & 2.8 & 83.2 & 93.6 \\
\hline 2012 & 92.3 & 5.4 & 86.9 & 3.7 & 79.2 & 91.8 & 92.8 & 2.4 & 90.4 & 3.2 & 84.4 & 94.7 \\
\hline 2013 & 91.3 & 6.4 & 84.9 & 4.9 & 74.3 & 90.8 & 94.0 & 1.7 & 92.3 & 3.5 & 84.9 & 97.7 \\
\hline 2014 & 89.3 & 5.0 & 84.4 & 3.3 & 77.9 & 88.7 & 92.3 & 2.5 & 89.8 & 2.5 & 84.0 & 93.5 \\
\hline 2015 & 92.3 & 5.0 & 87.3 & 3.7 & 78.6 & 91.7 & 93.8 & 2.4 & 91.4 & 2.1 & 87.3 & 95.7 \\
\hline 2016 & 95.4 & 6.6 & 88.8 & 5.1 & 76.8 & 94.8 & 95.9 & 2.9 & 92.9 & 3.7 & 85.1 & 100.3 \\
\hline 2017 & 98.1 & 9.7 & 88.4 & 8.2 & 70.2 & 97.5 & 98.6 & 3.1 & 95.6 & 5.6 & 84.8 & 105.0 \\
\hline
\end{tabular}

TE and BC_TE are the original technical efficiency and the bias-corrected technical efficiency, respectively Std indicates the standard deviation; Low and Up are the lower and upper bound of the 95\% confidence interval, respectively

The overall average original technical efficiency measured by the input-oriented approach is lower than that given by the RAM approach. Based on the original technical efficiency estimates, both approaches gave the same efficient bank-year observations: $26.1 \%$ of the sample bank-year observations appeared technically efficient. The number of efficient banks during the sample period varied from no efficient banks in 2002 and 2003 to eight efficient banks in 2017. More precisely, among the 10 banks in our sample, the number of efficient banks was seven in 1995 and decreased steadily to reach zero in 2002 and 2003. The number remained low, around one efficient bank until 2011, after which it increased to reach around three in subsequent years and eight in 2017. The dispersion of efficiency estimates was lower using the RAM approach. However, starting from 2014, the dispersion of efficiency estimates showed a similar, decreasing trend under the two approaches.

The evolution of the average original technical efficiency, as well as the average biascorrected technical efficiency estimates, are plotted and depicted in Fig. 1.

It is immediately noticeable that the original estimates are higher than the bias-corrected ones, implying that technical efficiency was overestimated by both approaches. However, the bias-corrected and original estimates depicted similar trends, detecting 


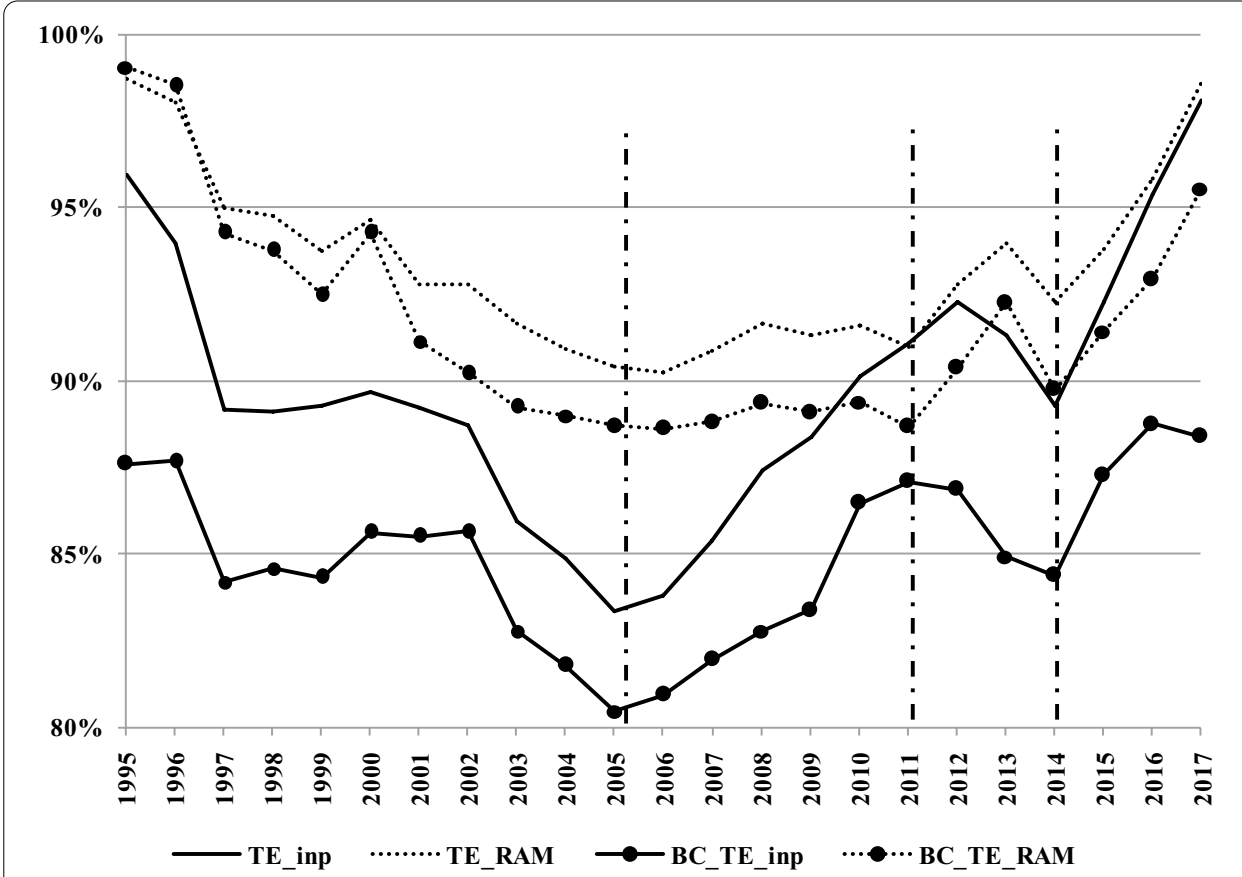

Fig. 1 Evolution of average original and bias-corrected technical efficiency estimates

the same ramp-up periods of technical efficiency: the first in 2005 and the second in 2014.

Regarding the improvement of technical efficiency detected just after 2005, unlike the RAM model which estimated a slower pace of increase in technical efficiency, the input-oriented model estimated a steeper increase. Hence, the undertaken reforms during early 2000 had a more pronounced effect based on targeting inputs only but not inputs and outputs at the same time. In particular, the regulatory measures adopted in early 2000, in hopes of increasing competition between banks and improving credit quality, had undoubtedly resulted in better management of the technical aspects of banking output production. However, assessing the management plans to reduce the inputs used to produce the targeted quantities of outputs (input-oriented), estimated higher than expected increases in technical efficiency. Thus, assessing the management plans adopted by the banking sector at that time, using models where inputs are solely targeted, can be misleading. It is more plausible to evaluate the gain in efficiency as a result of these reforms, based on Pareto efficiency, where a simultaneous reduction in inputs and an increase in outputs is possible. Consequently, the undertaken reforms adopted during the 2000s, led to a largely gradual recovery in overall banking technical efficiency, and not a considerable one. The World Bank (2014b) reports a more general performance of the Tunisian banking sector than our findings and notes that the banking reforms undertaken since the early 2000s, mainly consisting of making all banks universal, did not lead to the anticipated financial deepening. Consequently, banks did not sufficiently expand their financial services to cater to a greater set of customer needs and preferences, undermining improvements in technical efficiency. Moreover, the efforts made at that time to restructure 
Table 5 Comparison of average original and bias-corrected technical efficiency of banks by type of ownership before and after the revolution

\begin{tabular}{|c|c|c|c|c|c|c|c|c|}
\hline & \multicolumn{4}{|c|}{ Original technical efficiency } & \multicolumn{4}{|c|}{ Bias-corrected technical efficiency } \\
\hline & \multicolumn{2}{|c|}{ Public after } & \multicolumn{2}{|c|}{ Private before } & \multicolumn{2}{|c|}{ Public after } & \multicolumn{2}{|c|}{ Private before } \\
\hline & $\begin{array}{l}\text { Input- } \\
\text { oriented }\end{array}$ & RAM & $\begin{array}{l}\text { Input- } \\
\text { oriented }\end{array}$ & RAM & $\begin{array}{l}\text { Input- } \\
\text { oriented }\end{array}$ & RAM & $\begin{array}{l}\text { Input- } \\
\text { oriented }\end{array}$ & RAM \\
\hline Public before & Yes* $^{*}$ & Yes $^{*}$ & No & Yes*** & No & No & No & Yes $^{* * *}$ \\
\hline Private after & No & No & Yes*** & No & No & No & Yes** & No \\
\hline
\end{tabular}

Yes stands for reject $H_{0}: \mu_{1}=\mu_{2}$ at $1 \%\left({ }^{* * *}\right), 5 \%\left(^{* *}\right)$ and $10 \%\left({ }^{*}\right)$ significance level

state-owned commercial banks produced disappointing outcomes. This poor general banking performance, which can obviously affect technical efficiency, is explained by weak competition pressure among banks (Saadaoui 2018) associated with a loose regulatory framework (World Bank 2014b).

Starting from 2014, a clear improvement in technical efficiency is detected by the two models, witnessing the success of reforms and the financial and technical assistance received by the Tunisian banking sector after the 2011 revolution. In order to compare the technical efficiency of banks before and after the 2011 revolution, we conducted an equality of means test on the original and bias-corrected efficiency estimates. The results are reported in Table 5.

The means equality test on the original and bias-corrected technical efficiency estimates gave different results for public banks before and after the revolution. Hence, making inferences based on the original estimates is misleading. More precisely, the means equality test for the bias-corrected technical efficiency estimates revealed that the revolution had no significant impact on the technical efficiency of public banks. However, unlike the RAM model which predicted no significant effect from the revolution on the technical efficiency of private banks, the input-oriented model predicted that the technical efficiency of private banks differed significantly after the revolution. Consequently, the undertaken reforms immediately following the 2011 revolution most likely helped improve the technical efficiency of private banks.

Comparing the technical efficiency of private and public banks before the revolution, a significant difference was detected by the RAM model, but no significant effect was detected by the input-oriented model. Hence, drawing conclusions solely on the input-oriented model can be misleading. Evidently, before the revolution, private and public banks did not have the same level of technical efficiency. Concerning the technical efficiency of private and public banks after the revolution, both models indicate no significant differences between them. Hence, in the aftermath of the 2011 revolution, private and public banks were equally capable of managing the technical aspects of banking production.

In summary, after the revolution, the undertaken reforms allowed both bank types to attain similar levels of technical efficiency despite the differences that may have prevailed between their technical efficiency levels before the revolution. 
Table 6 Descriptive statistics of the variables used in the truncated regressions

\begin{tabular}{llllll}
\hline Variable & Obs & Min & Max & Average & Std. err \\
\hline Size & 230 & 5.8 & 7.1 & 6.5 & 0.3 \\
N_B & 230 & 29 & 207 & 106.7 & 39.3 \\
Staffing, in \% & 230 & 3.8 & 48.0 & 19.7 & 10.6 \\
ROA, in \% & 230 & -10.4 & 3.5 & 0.9 & 1.2 \\
ROE, in \% & 230 & -942.3 & 101.4 & 6.2 & 64.9 \\
EIR, in \% & 230 & -31.5 & 69.9 & 39.6 & 9.1 \\
LDR, in \% & 230 & 54.2 & 239.9 & 104.9 & 22.6 \\
LAR, in \% & 230 & 43.4 & 91.6 & 71.6 & 9.8 \\
CAR, in \% & 230 & -1.6 & 17.5 & 8.9 & 3.0 \\
Inflation, in \% & 230 & 2.0 & 6.2 & 3.8 & 1.1 \\
Growth, in \% & 230 & -1.9 & 7.1 & 3.7 & 2.1 \\
\hline
\end{tabular}

In the second stage of analysis, the double bootstrapping technique is applied to Eq. (4) under each approach. The descriptive statistics of the variables included in the model are given in Table 6 .

The pre-regression diagnosis for multicollinearity starts by determining and examining the bivariate correlation coefficients displayed in Table 7. Three groups of highly correlated variables can be easily distinguished. The first includes bank size (Size), number of branches (N_B), and management to staff ratio (Staffing). The second includes return on equity (ROE) and return on assets (ROA), and the third group includes loan to asset ratio (LAR) and loan to deposit ratio (LDR). Hence, by including only one variable from each highly correlated group of variables, we identified 12 possible multicollinearity-free regressions. The parameter estimates of all explanatory variables are produced by double bootstrapping each possible regression for the input-oriented and the RAM technical efficiency and given in Tables 8 and 9, respectively.

In addition to the internal and external variables included in each model to explain the measured DEA efficiency, we included time as an explanatory variable in order to reflect any technical changes that may have occurred during our sample study. We also added two dummy variables. The first is Revolution and stands for the period before and after the 2011 revolution. The second dummy variable is Ownership and stands for private and public banks. Hence, the general form of Eq. (4) becomes:

$$
\begin{aligned}
& T E_{i t}=\alpha_{0}+\alpha_{1} \text { Time }+\alpha_{2} \text { Size }_{i t}+\alpha_{3} N_{-} B_{i t}+\alpha_{4} \text { Staffing }_{i t}+\alpha_{5} \text { ROA }_{i t}+\alpha_{6} \text { ROE }_{i t} \\
& \quad+\alpha_{7} \text { EIR }_{i t}+\alpha_{8} L_{\text {LDR }}+\alpha_{i t} \text { LAR }_{i t}+\alpha_{10} \text { CAR }_{i t}+\alpha_{11} \text { Inflation }_{t}+\alpha_{12} \text { Growth }_{t} \\
& \quad+\alpha_{13} \text { Revolution }_{i}+\alpha_{14} \text { Ownership }_{i}+\varepsilon_{i t}
\end{aligned}
$$

To verify the consistency and robustness of the obtained estimates, the summary results of the effect of each potential determinant on banking technical efficiency under the two approaches are combined and displayed in Table 10.

Our results reveal that time is statistically significant and positively related to technical efficiency in all the input-oriented regressions and two-thirds of the RAM bootstrap technical efficiency regressions. This positive, but weak (less than an average of $1 \%$ gain 


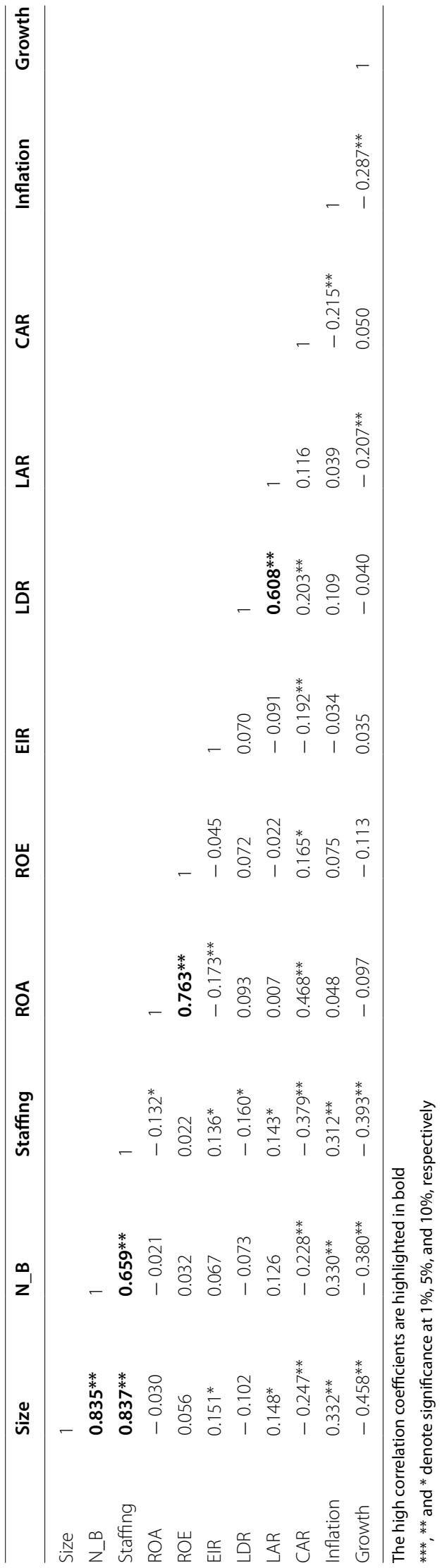




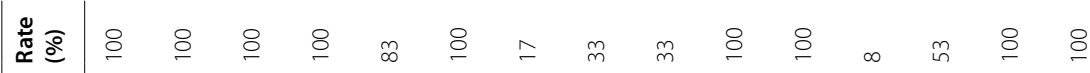

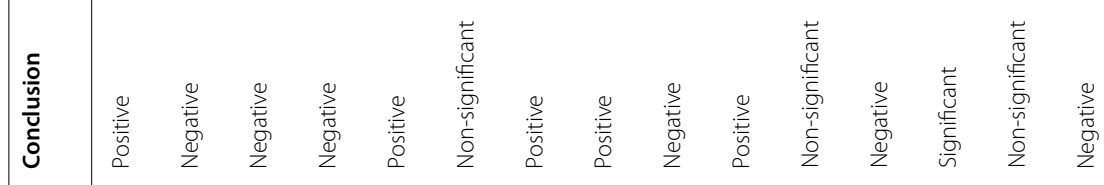

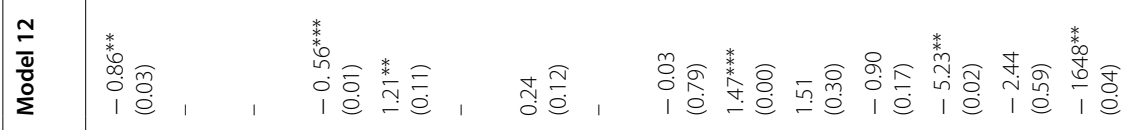

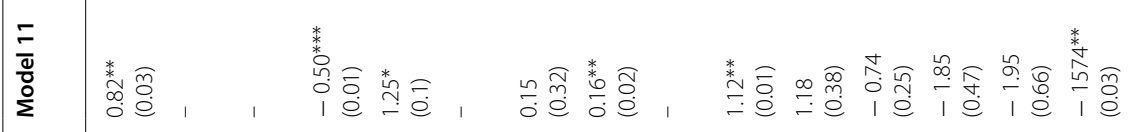

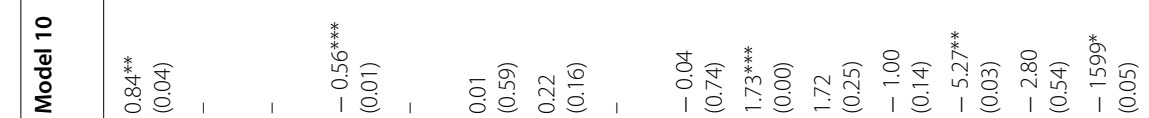

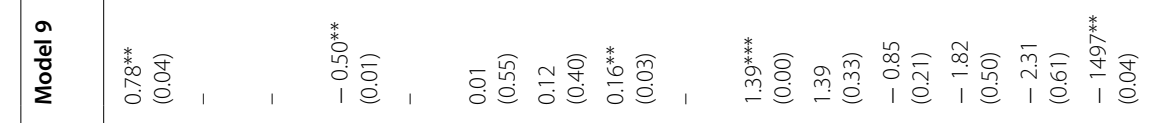

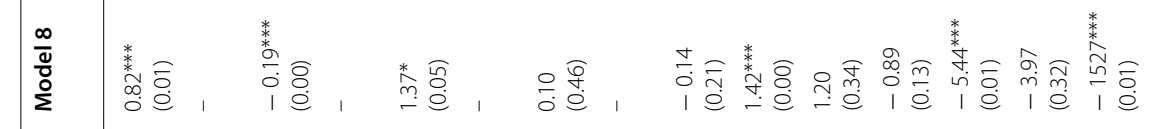

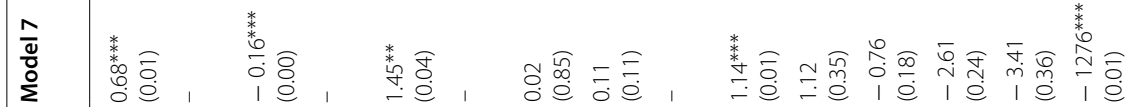

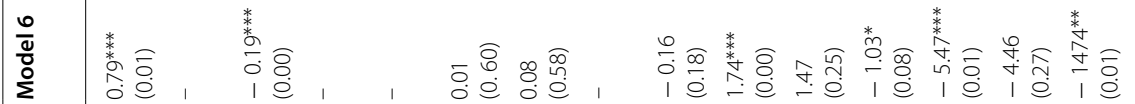

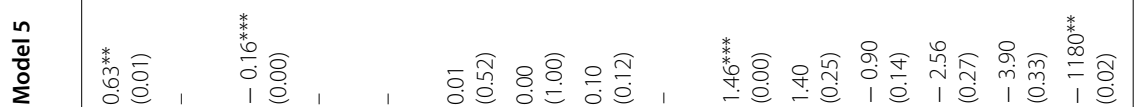

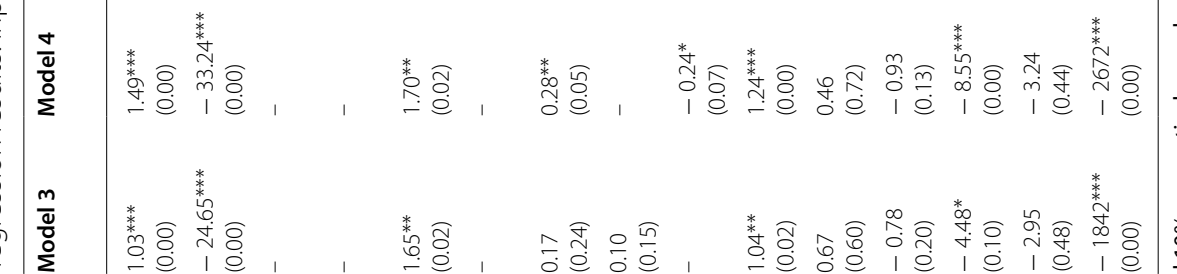
类

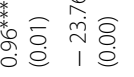

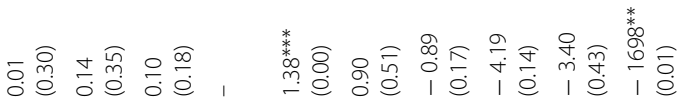




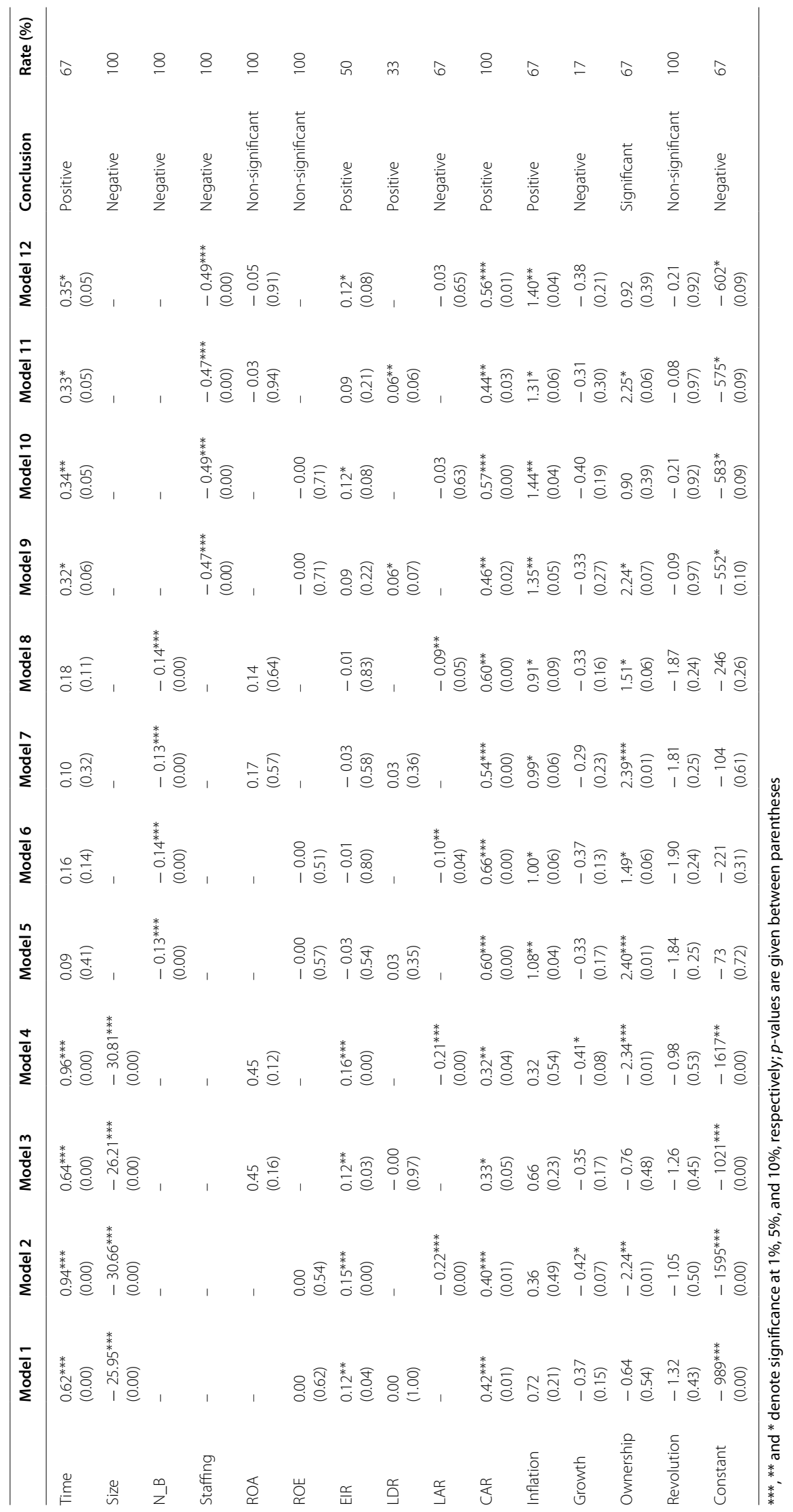


Table 10 Summary results of the double bootstrap regressions

\begin{tabular}{|c|c|c|c|c|}
\hline \multirow[t]{2}{*}{ Variable } & \multicolumn{2}{|c|}{ Input-oriented } & \multicolumn{2}{|l|}{ RAM } \\
\hline & Sign & Rate (\%) & Sign & Rate (\%) \\
\hline Time & + & 100 & + & 67 \\
\hline Size & - & 100 & - & 100 \\
\hline N_B & - & 100 & - & 100 \\
\hline Staffing & - & 100 & - & 100 \\
\hline $\mathrm{ROA}$ & + & 83 & NS & 100 \\
\hline ROE & NS & 100 & NS & 100 \\
\hline EIR & + & 17 & + & 50 \\
\hline LDR & + & 33 & + & 33 \\
\hline LAR & - & 33 & - & 67 \\
\hline CAR & + & 100 & + & 100 \\
\hline Inflation & NS & 100 & + & 67 \\
\hline Growth & - & 8 & - & 17 \\
\hline \multirow[t]{2}{*}{ Ownership } & - & 58 & + & 50 \\
\hline & & & - & 17 \\
\hline Revolution & NS (-) & 100 & NS (-) & 100 \\
\hline
\end{tabular}

NS non-significant

per year in technical efficiency by the RAM bootstrap regressions), relationship between banking technical efficiency and time indicates that the substantial recovery brought about after 2005, slightly outweighed the continuous fall that persisted during the preceding decade. Hence, the technical progress in the banking sector during the last two decades was followed by an overall minimal improvement in technical efficiency. This is also a clear indication that during the last two decades, the banking sector was sluggish in keeping up with evolving technologies. For instance, despite the efforts made to modernize their information systems, without forgetting the engagement of state-owned banks in politicized lending, most Tunisian banks have been managing risk with no reliable information system on their clients, making them inefficient in channeling funds to the economy, besides incurring high non-performing loans. In fact, only in 2016 did the central bank issue circular No. 2016-06 by which banks are enforced to implement a reliable rating system for their debtors. However, we must recognize that, recently, the central bank authorities engaged in making fintech operations easier despite the prevailing rigid regulatory framework. This willingness to rely on fintech to build a modern and more efficient banking system is supported for instance by Kou et al. (2021a) who found that, for European banking services, fintech-based investments and specifically payment and money transferring systems decrease banking operational costs and hence can increase efficiency through sales volume increases.

Size was found to be significant and negatively related to technical efficiency in all bootstrap regressions. Hence, unlike Ayadi (2014) and Chenini and Jarboui (2018) who found that bank size is insignificant in explaining technical efficiency over the period of 2000-2011, and contrary to Ben Romdhane (2013) and Tlig and Hamed (2017), we can conclude that larger banks in terms of total assets are characterized by being less technically efficient. Thus, larger banks in Tunisia are likely more difficult to manage due to the bureaucracy and mismanagement of public banks. This finding 
is not consistent with the positive relationship between bank size and technical efficiency that was found by most of the earlier studies. Our results indeed complement the argument made by the World Bank (2014b) that the Tunisian banking sector is characterized by its atomized structure, which may limit scale economies. Consequently, reaping the benefits of economies of scale from asset size expansion as suggested by Djebali and Zaghdoudi (2020), for example, is possible for Tunisian banks only if they are able to successfully manage the operations system of larger banks.

N_B was also found to be significant and negatively related to technical efficiency in all bootstrap technical efficiency regressions. However, this effect is very small in magnitude, attaining a maximum average of $0.2 \%$ loss in efficiency per additional bank branch. Unlike Repkova (2015) who found no significant effect for the number of branches, and contrary to Bannour and Labidi (2013), the technical efficiency of Tunisian banks may not increase with the broadening of their distribution networks. Hence, getting geographically closer to its clients does not enhance technical efficiency if the quantities of inputs needed are not accompanied by sufficient increases in outputs. This suggests that bank managers must better assess their strategies to expand or reduce the bank's distribution network by opening new agencies or closing existing ones to maintain a level at which an overall gain in technical efficiency is possible.

Staffing was found to be significantly and negatively related to technical efficiency in all bootstrap regressions. However, the magnitude of this relationship is very small, varying slightly around an average of $0.5 \%$ loss in efficiency. Hence, adopting a tall organizational structure or a flat one can affect technical efficiency. Our results are contradictory to those reported in Ben Romdhane (2013) who found a significant and positive relationship between the ratio of senior managers to total bank workforce and the technical efficiency of Tunisian banks over the period of 1998-2009. Our sample period exceeds by far that studied by Ben Romdhane (2013), during which the marginal contribution of executives to technical efficiency was probably still increasing. In fact, efficiency gains from a tall organizational structure, stemming from close supervision of employees, obvious lines of responsibilities, and a clearer promotion structure are most likely nullified by the loss in efficiency from delays in decisionmaking and lack of implication of top-level managers to improve work process. Our results also indicate that despite the efforts made over the whole sample period, the work process and functions in Tunisian banks did not manage to break from the significant bureaucracy and a rigid, out-of-date banking culture.

ROA was shown to be positive but insignificant by all bootstrap RAM regressions and significantly and positively related to technical efficiency by almost all input-oriented bootstrap technical efficiency regressions. Hence, our results provide additional evidence of the positive relationship between ROA and technical efficiency that was found by most of the earlier studies (Saha et al. 2015; Tadesse 2017; Banna et al. 2019). It is, however, partially in line with the findings of Bannour and Labidi (2013). When bank managers can alter both inputs and outputs, ROA becomes insignificant in explaining technical efficiency. Hence, seeking higher profits out of the bank's total assets can indicate an improvement in technical efficiency only when efficiency is measured by minimizing inputs to produce fixed amounts of outputs, and not when minimizing inputs 
and maximizing outputs simultaneously. This could be explained by the low competitiveness of the Tunisian banking environment where banks can reach long-run profit objectives without experiencing major improvements in the technical aspects of their banking operations. This is also reflected by the ROE, which was found to be insignificant in all bootstrap regressions, indicating that the ROE also does not explain the technical efficiency of Tunisian banks during the examined period. Hence, a higher profit per unit of investors' money put in the bank's capital does not result in improved efficiency. The consistency of the effect of the profitability measures on technical efficiency is further reinforced by the EIR, which was also found to be insignificant by most of the bootstrap input-oriented regressions and half of the bootstrap RAM regressions. For Tunisian banks, the expenses are mainly interests and commissions paid, whereas gross banking income is mainly interests earned, hence a lower EIR corresponds to higher interest margins. Therefore, as Saadaoui (2018) indicated, higher interest margins do not necessarily lead to higher bank efficiency, adding more evidence to the fact that low competition prevailing in the Tunisian banking environment made banks reluctant to look for more efficiency.

LDR was found to be significant and positively related to technical efficiency with limited effect in a few bootstrap regressions. Hence, this result is weakly in line with Ben Naceur et al. (2011) and contradicts the findings of Bannour and Labidi (2013) who found the LDR to be negatively related to technical efficiency. In particular, our results indicate that a higher liquidity risk may render some Tunisian banks more technically efficient by expanding output despite the risk of incurring higher banking operating costs. In fact, on one hand, lending too much of its deposits may oblige the bank to borrow with high interest rates. On the other, lending too few of its deposits may incur a high opportunity cost of lost revenues. Hence, determining the proper loan to deposit ratio is a delicate balance for banks. In 2018, the Tunisian central bank issued circular No. 2018-10, compelling banks to not have a loan to asset ratio exceeding $120 \%$. Such a liquidity risk level seems to be sufficiently high to induce banking technical efficiency. In fact, most of the banks with loan to deposit ratios exceeding $120 \%$ were public ones. Therefore, besides pursuing the encouragement of banks to improve their managerial performance, the central bank of Tunisia targeted public banks, calling on them to reduce their risk of incurring high bank operating costs by holding reasonable liquidity positions.

LAR was found to be negative and significant in one-third of bootstrap input-oriented regressions and in two-thirds of the bootstrap RAM regressions. This result is in contrast to the positive relationship between loan to asset ratio and technical efficiency that was commonly found by previous studies, such as Sufian (2009), Sufian and Habibullah (2010), Batir et al. (2017), and Jiménez-Hernández et al. (2019). Hence, over relatively long horizons, Tunisian banks with a high loan to asset ratio are more likely less efficient, suggesting that the loan market in Tunisia cannot be the result of efficient operations. More precisely, in addition to the fact that over sufficiently long horizons, bank loans become less valued than alternative bank outputs, such as investment in securities, interbank loans, and off-balance sheet commitments, the loans in Tunisia are not provided based on efficient management operations and lower production costs. Hence, larger loan market shares are more likely obtained by less efficient banks. 
CAR was found to be significant and positively related to technical efficiency in all bootstrap regressions. Hence, as in Ayadi (2014), our result adds more evidence to the general consensus among earlier studies that well capitalized banks are more technically efficient (Sufian and Habibullah 2010; Ben Naceur et al. 2011; Saha et al. 2015; Repkova 2015; Tadesse 2017; Banya and Biekpe 2018; Banna et al. 2019). These findings imply that more efficient banks tend to use less leverage, thus holding more equity which encourages them to engage in riskier operations and increase their output. Such banks are more solvent and financially more stable as they can support more reasonable losses and have lower financial risk. Nevertheless, financial technology and recent advances in financial risk analysis, as introduced by Kou et al. (2014) among others, can be applied by banks to help them hedge against uncertainties and enhance their efficiency.

Concerning external factors, inflation was found to be non-significant and positively related to technical efficiency in all bootstrap input-oriented regressions and significantly and positively related to technical efficiency in two-thirds of the bootstrap RAM regressions. Hence, our result contradicts that of Batir et al. (2017) and Banna et al. (2019), revealing that, for Tunisia, inflation may increase the technical efficiency of banks. Sufian and Habibullah (2012) attribute the extent to which inflation affects bank efficiency to whether inflation is fully anticipated or not. Since the late 1980s banks in Tunisia have been free to set their interest rates but within a margin. Currently, banks are allowed to negotiate the interest rate with their clients within a minimum level of money market average (MMA) and a maximum of MMA $+7 \%$. Since the central bank of Tunisia has always been gauging the prospects of inflation pressures and revising its benchmark interest rate on a monthly basis, Tunisian banks are able to anticipate inflation and therefore do not cut back the amount of loans they provide to the economy. Instead, they adjust the interest rate accordingly and improve their technical efficiency. Importantly, the interest rate had long been used by the Tunisian central bank to stabilize prices, and the direct link between the interest and inflation rate is significant (Boughzala and Moussa 2011). Consequently, stabilizing inflation helped reduce uncertainty, to predict changes in interest rates and to anchor inflation expectations.

Economic growth was found to be insignificant in almost all bootstrap regressions, indicating that economic development does not affect the managerial efficiency of banks. This result is different from that of Sufian (2009), Batir et al. (2017), and Repkova (2015) who found that economic growth negatively affects technical efficiency. Hence, in the Tunisian case, the amount of loans provided by banks to the economy did not depend on the level of economic activity. In fact, despite increased private sector demand for loans during the period of economic booms, the supply of loans by banks seemed to be relatively inelastic, resulting in no detectable change in their technical efficiency. This may be explained by the fact that banks in Tunisia rely heavily on collateral as guarantees for loans, as reported in De Lima et al. (2016). More precisely, Tunisian banks usually respond positively to any loan demand by large enterprises and always apply their strict requirements to any loan demand by SMEs, despite receiving acceptable financial statements. Adair and Fhima (2013) provide evidence for the period of 2001-2006 that the amount of bank loans provided to SMEs are far from their expressed financing needs. This lack was justified by the inability of SMEs 
to fulfill the excessive cost of financing and provide the real guarantees imposed by banks. In fact, evaluating the credit risk of SMEs by banks is usually complicated and costly due to the lack of reliable accounting data and the limitations of financial statements. To help banks meet their need to effectively rate SMEs, Kou et al. (2021b) proposed a practical bankruptcy prediction model for SMEs that uses the payment and transactional data available to banks. Such a bank-provided data model can help reduce banks' heavy reliance on collateral as guarantees for loan demands by SMEs, thus increasing finance access to more businesses and enhancing banking technical efficiency.

The bootstrap regressions complement the non-parametric equality of the means test and provide us with the sign of the effect of the ownership structure on technical efficiency. Over the whole sample period, the technical efficiency of public banks was found to be on average higher than that of their private counterparts in slightly more than half of the bootstrap input-oriented regressions and a few bootstrap RAM regressions. Nevertheless, half of the bootstrap RAM regressions indicated that private banks were on average more technically efficient than public banks. Hence, our results partially contradict those of Ayadi (2014) who found that the technical efficiency of private banks was better than that of public ones over the period of 2000-2011.

All bootstrap technical efficiency regressions gave negative, but non-significant, coefficients for the dummy variable Revolution, indicating that overall technical efficiency improved after the revolution but not significantly. Hence, the bootstrap regressions complemented the results found by the non-parametric equality of means test to ascertain that both types of banks did not realize sufficient improvements in their technical efficiency after the 2011 revolution to outweigh the accumulated previous losses.

Prior to the 2011 revolution, state-owned banks had been abused by the political power to provide loans to cronies and well connected business, without caring about the risk associated with such loans since sufficient capital was injected whenever needed to avoid bankruptcy (World Bank 2014b). Hence, during the last two decades, public banks did not care about non-performing loans and had higher technical efficiency than their private counterparts as a result of the high amount of loans provided to the economy rather than to better management of banking operations. Immediately after the revolution, the central authorities began to advocate for stricter banking regulations to make state-owned banks more competitive. Moreover, in 2014, the three state-owned banks have undergone restructuring and modernization efforts following an audit of their finances. They were also recapitalized with the condition of internal restructuring, including the addition of independent administrators to the board of directors, unlike several times in the last two decades when public banks received significant, unconditional recapitalization. 


\section{Conclusions}

This study investigates the technical efficiency of Tunisian commercial banks during the last two decades with radial and non-radial bootstrap DEA. First, technical efficiency estimates were evaluated using the input-oriented and RAM model approach. Then, a set of eventual determinants of technical efficiency were investigated using the double bootstrap regression technique.

The obtained estimates of technical efficiency, under the two alternative approaches, displayed similar evolutions of their averages over the whole sample period. They all detected two major rise-up periods in average technical efficiency: the first in 2005 and the second in 2014. For 2005, unlike the radial approach which detected a more pronounced uptick in technical efficiency, the non-radial approach detected only a slight increase. Consequently, the regulatory reforms of early 2000, intended to increase competition among banks, did not result in substantial long-term improvements in the technical aspects of producing banking outputs. While for 2014, the two approaches detected a noticeable increase in banking technical efficiency, witnessing the success of the post-2011 revolution reforms largely revolving around bank supervision and conditional restructuring of public banks. Specifically, before the 2011 revolution, public banks were on average outperforming private ones in terms of technical efficiency, not because of better managerial performance in conducting banking operations, but because public banks being abused by the political system to provide loans to well-connected businesses and state-owned enterprises without concern for the associated risk, since the banks were receiving unconditional capitalization whenever needed. Hence, ending the abuse of state-owned banks can stop distorting the operations management performance of the Tunisian banking sector.

The empirical results gauged the effect of each determinant on technical efficiency and provided several helpful implications and recommendations. First, during the last two decades, the effect of technical progress on the technical efficiency of the banking sector was very weak. More precisely, we provide evidence that the banking sector in Tunisia lagged in coping with current technologies despite the modernization efforts made. Consequently, banks that are lagging are recommended to invest in the acquisition and utilization of new technology and, specifically, information technology and operational tools that can help them evaluate projects correctly, quickly, and with lower cost. Banks must also not forget about providing regular and adequate training to maintain high human capital levels for its managers and workers.

Second, bank size was shown to be significant and negatively related to technical efficiency. Hence, the gain from economies of scale, by expanding through acquisition of small banks or merging certain banks, depends strongly on the successful management of larger banks. Moreover, expanding by getting geographically closer to their clients through their distribution network must be carefully evaluated, since the technical efficiency of banks was found to be negatively and weakly related to the number of bank branches.

Third, most of the profitability measures proved to be insignificant to technical efficiency, suggesting that banks in Tunisia had been operating in a low competitive environment. More precisely, our results suggest that during the last two decades, the banking sector was able to realize long-run profit objectives without big concerns about 
improvements in the technical aspects of their banking operations. Hence, in order to increase the technical efficiency of banks, a more competitive banking environment must be created. This can be achieved for instance, by removing limitations on the interest rates charged on loans, continuing with the development of the capital market as an alternative financing source to bank loans, sticking firmly to bank supervision, and sanctioning any violation of the rules.

Fourth, the technical efficiency of the Tunisian banking sector increases with capitalization. Thus, well capitalized banks are prone to take more risks and increase their output, hence improving their efficiency. Consequently, in order to increase the overall technical efficiency of Tunisian banks, the minimum level requirement for banks' equity capital could be revised by central bank authorities.

Finally, our results reveal that technical efficiency is not dwindled by the economic instability resulting from high inflation as banks are able to anticipate inflation, adjust their interest rate accordingly, and hence can increase their technical efficiency. On the other hand, economic activity was shown to be insignificant to technical efficiency, indicating that the supply of bank loans to the economy is rather inelastic. Thus, banks are recommended to revise their collateralization of loans to ease access to finances for more businesses.

Since technical efficiency places greater emphasis on the volume of inputs and outputs rather than on their quality, this study can be enriched by including some proxies for output quality as loan loss provisions, average time needed to respond to a loan demand by SMEs, or proxies for input quality such as overhead costs. However, this may depend on the availability of such data at the bank level. In addition, measuring the productivity of commercial banks and investigating the changes in their productivity can also be performed. The Malmquist index can be applied to decompose the change in productivity for each bank into technical, technological, and scale changes. Hence, we can enrich our assessment of the banking sector by obtaining the evolution of each component of the productivity index and provide insights on the causes of productivity changes.

\section{Abbreviations}

RAM: Range adjusted measure; GDP: Gross domestic product; DEA: Data envelopment analysis; MENA: Middle East and North African; VRS: Variable returns to scale; EU: European Union; DCFTA: Deep and comprehensive free trade area; IMF: International monetary fund; SMEs: Medium sized enterprises; NAB: National agricultural bank; TBC: Tunisian banking company; BH: Bank of housing; TPABFI: Tunisian professional association of banks and financial institutions; ECM: Efficiency contribution measure; DMUs: Decision-making units; Size: Bank size; N_B: Number of branches; Staffing: Management to staff ratio; ROA: Return on assets; ROE: Return on equity; EIR: Expense to income ratio; LDR: Loan to deposit ratio; LAR: Loan to asset ratio; CAR: Capital to asset ratio; Inflation: Inflation rate; Growth: Real growth rate; Revolution: 2011 Social revolution; Ownership: Ownership structure of banks: private or public; MMA: Money market average.

\section{Acknowledgements}

The authors are very grateful to the editor-in-chief and five anonymous reviewers for detailed comments and helpful suggestions that greatly enhanced the quality of the paper.

\section{Authors' contributions}

Both authors collaborated closely on the subject. In particular, MMJ went over the literature, collected and prepared the data, analyzed and discussed the results, and put the paper into its final shape, while ED assisted with the methodology and results part. Both authors read and approved the final manuscript.

\section{Funding}

No funds were received for this manuscript.

Availability of data and materials

Data were collected from published balance sheets and income statements of each bank in annual reports released by the Tunisian Professional Association of Banks and Financial Institutions. 


\section{Declarations}

Competing interests

The authors declare that they have no competing interests.

Received: 27 July 2020 Accepted: 9 August 2021

Published online: 16 August 2021

\section{References}

Adair P, Fhima F (2013) Le financement des PME en Tunisie: Dépendance à l'égard des banques et rationnement du crédit. Revue internationale PME 26(3-4):117-138. https://doi.org/10.7202/1024521ar

Andersen TB, Tarp F (2003) Financial liberalization, financial development and economic growth in LDCs. J Int Dev 1(52):189209. https://doi.org/10.1002/jid.971

Avkiran NK, Morita H (2010) Predicting Japanese bank stock performance with a composite relative efficiency metric: a new investment tool. Pac Basin Finance J 18:254-271. https://doi.org/10.1016/j.pacfin.2010.01.002

Avkiran NK, McCrystal A (2014) Dynamic network range-adjusted measure vs. dynamic network slacks-based measure. J Oper Res Soc Jpn 57(1):1-14. https://doi.org/10.15807/jorsj.57.1

Ayadi I (2014) Technical efficiency of Tunisian banks. Int Bus Rev 7(4):170-182. https://doi.org/10.5539/ibr.v7n4p170

Banna H, Shah SKB, Noman AHM, Ahmad R, Masud MM (2019) Determinants of sino-ASEAN banking efficiency: How do countries differ? Economies 7(1):1-23. https://doi.org/10.3390/economies7010013

Bannour B, Labidi M (2013) Efficience des banques commerciales Tunisiennes: Etude par l'approche de frontière stochastique. Panoeconomicus 60(1):103-132. https://doi.org/10.2298/PAN1301103B

Banya R, Biekpe N (2018) Banking efficiency and its determinants in selected frontier African markets. Econ Change Restruct 51(1):69-95. https://doi.org/10.1007/s10644-016-9200-3

Batir TE, Volkman DA, Gungor B (2017) Determinants of bank efficiency in Turkey: participation banks versus conventional banks. Borsa Istanb Rev 17(2):86-96. https://doi.org/10.1016/j.bir.2017.02.003

Ben Naceur S, Casu B, Ben Khedhiri H (2011) What drives the performance of selected MENA banks? A meta-frontier analysis. IMF Working Papers 11/34, International Monetary Fund. https://doi.org/10.5089/9781455217922.001

Ben Romdhane S (2013) Impact of information technology on the performance of Tunisian banks: a stochastic frontier analysis with Panel Data. Asian Acad Manag J Account Finance: AAMJAF 9(2):95-125

Berger AN, Humphrey DB (1997) Efficiency of financial institutions: international survey and directions for future research. Eur J Oper Res 98:175-212. https://doi.org/10.1016/S0377-2217(96)00342-6

Berger AN, Hancock D, Humphrey DB (1993) Bank efficiency derived from the profit function. J Bank Finance 17(2-3):317-347. https://doi.org/10.1016/0378-4266(93)90035-C

Boughzala M, Moussa H (2011) The Uncertain journey towards inflation targeting in Tunisia. In: Boughzala M, Cobham D (eds) Inflation targeting in MENA countries. Palgrave Macmillan, London, pp 256-286. https://doi.org/10.1057/9780230316 $560 \quad 10$

CBT (2017) Central Bank of Tunisia: annual report on banking supervision. https://www.bct.gov.tn/bct/siteprod/documents/ sup_bc_ang.pdf

Chan S-G, Karim MZA (2010) Bank efficiency and macro-economic factors: the case of developing countries. Glob Econ Rev 39(3):269-289. https://doi.org/10.1080/1226508X.2010.513141

Chang M-C (2013) The technology management efficiency of banks under Taiwanese financial holding companies. J Appl Econ Bus Res 3(4):192-206

Chenini H, Jarboui A (2018) Analysis of the impact of governance on bank performance: case of commercial Tunisian banks. J Knowl Econ 9(3):871-895. https://doi.org/10.1007/s13132-016-0376-6

Chiu C-R, Chiu Y-H, Fang C-L, Pang R-Z (2014) The performance of commercial banks based on a context-dependent rangeadjusted measure model. Int Trans Oper Res 21(5):761-775. https://doi.org/10.1111/itor.12069

Cooper WW, Park KS, Pastor JT (1999) RAM: a range adjusted measure of efficiency. J Prod Anal 11:5-42. https://doi.org/10 1023/A:1007701304281

Cooper WW, Seiford ML, Tone K (2007) Data envelopment analysis: a comprehensive text with models, applications, references and DEA-solver software, 2nd edn. Springer, Boston

Daraio C, Simar L, Wilson PW (2018) Central limit theorems for conditional efficiency measures and tests of the 'separability' condition in non-parametric, two-stage models of production. Econom J 21(2):170-191. https://doi.org/10.1111/ectj. 12103

De Lima P, Revoltella D, Rodriguez MJL, Schweiger H (2016) What's holding back the private sector in MENA? lessons from the enterprise survey. World Bank Group, Washington. http://documents.worldbank.org/curated/en/170531469775655994/ Whats-holding-back-the-private-sector-in-MENA-lessons-from-the-enterprise-survey

Djebali N, Zaghdoudi K (2020) Testing the governance-performance relationship for the Tunisian banks: a GMM in system analysis. Financ Innov 6:23. https://doi.org/10.1186/s40854-020-00182-5

Du K, Worthington AC, ZelenyukV (2018) Data envelopment analysis, truncated regression and double-bootstrap for panel data with application to Chinese banking. Eur J Oper Res 265(2):748-764. https://doi.org/10.1016/j.ejor.2017.08.005

Garza-Garcia JG (2012) Determinants of bank efficiency in Mexico: a two stage analysis. Appl Econ Lett 19:1679-1682. https:// doi.org/10.1080/13504851.2012.665589

International Monetary Fund (2016) Tunisia: Request for an Extended Arrangement Under the Extended Fund FacilityPress Release; Staff Report; and Statement by the Executive Director for Tunisia. IMF Staff Country Rep 16(138):1. https://doi.org/10.5089/9781484373149.002

Jiménez-Hernández I, Palazzo G, Sáez-Fernández FJ (2019) Determinants of bank efficiency: evidence from the Latin American banking industry. Appl Econ Anal 27(81):184-206. https://doi.org/10.1108/AEA-09-2019-0027 
Kou G, Peng Y, Wang G (2014) Evaluation of clustering algorithms for financial risk analysis using MCDM methods. Inf Sci 275:1-12. https://doi.org/10.1016/j.ins.2014.02.137

Kou G, Akdeniz ÖO, Dinçer H, Yüksel S (2021a) Fintech investments in European banks: a hybrid IT2 fuzzy multidimensional decision-making approach. Financ Innov 7:39. https://doi.org/10.1186/s40854-021-00256-y

Kou G, Xu Y, Peng Y, Shen F, Chen Y, Chang K, Kou S (2021 b) Bankruptcy prediction for SMEs using transactional data and two-stage multiobjective feature selection. Decis Support Syst 140:113429. https://doi.org/10.1016/j.dss.2020. 113429

Matta S, Appleton S, Bleaney M (2019) The impact of the Arab spring on the Tunisian economy. World Bank Econ Rev 33(1):231-258. https://doi.org/10.1093/wber/hw059

Nataraja NR, Johnson AL (2011) Guidelines for using variable selection techniques in data envelopment analysis. Eur J Oper Res 215(3):662-669. https://doi.org/10.1016/j.ejor.2011.06.045

Pastor JT, Ruiz JL, Sirvent I (2002) A statistical test for nested radial DEA models. Oper Res 50(4):728-735. https://doi.org/10.1287/ opre.50.4.728.2866

Repkova I (2015) Banking efficiency determinants in the Czech banking sector. Procedia Econ Finance 23:191-196. https://doi. org/10.1016/S2212-5671(15)00367-6

Saadaoui Z (2018) Dealing with high bank interest margins in Tunisia: a dynamic panel investigation. Afr Dev Rev 30(4):434-448. https://doi.org/10.1111/1467-8268.12350

Saha A, Ahmad NH, Dash U (2015) Drivers of technical efficiency in Malaysian banking: a new empirical insight. Asian Pac Econ Lit 29(1):161-173. https://doi.org/10.1111/apel.12091

Sealey CW, Lindley JT (1977) Inputs, outputs, and a theory of production and cost at depository financial institutions. J Finance 32(4):1251-1266. https://doi.org/10.1111/j.1540-6261.1977.tb03324.x

Shazida Jan MK, Shamzaeffa S, Rabiul I (2017) Efficiency of banks in Southeast Asia: Indonesia, Malaysia, Philippines and Thailand. Int J Soc Econ 44(12):2302-2312. https://doi.org/10.1108/ISE-01-2016-0020

Simar L, Wilson PW (2000) A general methodology for bootstrapping in non-parametric frontier models. J Appl Stat 27(6):779_ 802. https://doi.org/10.1080/02664760050081951

Simar L, Wilson PW (2007) Estimation and inference in two-stage semi-parametric models of production process. J Econom 136:31-64. https://doi.org/10.1016/j.jeconom.2005.07.009

Simar L, Wilson PW (2011) Two-stage DEA: caveat emptor. J Prod Anal 36(2):205-218. https://doi.org/10.1007/ s11123-011-0230-6

Sufian F (2009) Determinants of bank efficiency during unstable macroeconomic environment: empirical evidence from Malaysia. Res Int Bus Finance 23(1):54-77. https://doi.org/10.1016/j.ribaf.2008.07.002

Sufian F, Habibullah MS (2010) Developments in the efficiency of the Thailand banking sector: a DEA approach. Int J Dev Issues 9:226-245. https://doi.org/10.1108/14468951011073316

Sufian F, Habibullah MS (2012) Globalization and bank efficiency nexus: symbiosis or parasites? Rev Dev Finance 2:139-155. https://doi.org/10.1016/j.rdf.2012.09.003

Tadesse ZL (2017) Determinants of bank technical efficiency: evidence from commercial banks in Ethiopia. Cogent Bus Manag. https://doi.org/10.1080/23311975.2016.1268356

Tan Y (2016) The measurement of bank efficiency and bank risk in China. In: Investigating the performance of Chinese banks: efficiency and risk features. Palgrave Macmillan Studies in Banking and Financial Institutions. Palgrave Macmillan, London, pp 105-128. https://doi.org/10.1057/978-1-137-49376-7_5.

Tasnim N, Afzal MNI (2018) An empirical investigation of country level efficiency and national systems of entrepreneurship using Data Envelopment Analysis (DEA) and the TOBIT model. J Glob Entrep Res. https://doi.org/10.1186/ s40497-018-0138-y

Teti A, Abbott P, Cavatorta F (2018) The Arab uprisings in Egypt, Jordan and Tunisia: social, political and economic transformations. Reform and Transition in the Mediterranean, Palgrave Macmillan, Cham. https://doi.org/10.1007/978-3-319-69044-5

Thrall RM (1996) Duality, classification and slacks in DEA. Ann Oper Res 66:3-45. https://doi.org/10.1007/BF02187297

Tlig H, Hamed A (2017) Assessing the efficiency of commercial Tunisian banks using fuzzy data envelopment analysis. J Data Envel Anal Decis Sci 2017(2):14-27. https://doi.org/10.5899/2017/dea-00146

Tone K, Tsutsui M (2010) Dynamic DEA: a slacks-based measure approach. OMEGA Int J Manag Sci 38:145-156. https://doi.org/ 10.1016/j.omega.2009.07.003

Tröster B, Raza W, Grohs H, Grumiller J, Staritz C, Von Arnim R (2018) The EU-Tunisia Deep and Comprehensive Free Trade Area (DCFTA): macroeconomic impacts and pro-developmental policy responses, ÖFSE Policy Note, No. 28/2018, Austrian Foundation for Development Research (ÖFSE), Vienna

World Bank (2010) Tunisia development policy review: towards innovation-driven growth. World Bank. https:/openknowledge. worldbank.org/handle/10986/2955

World Bank (2014a) The unfinished revolution: bringing opportunity, good jobs and greater wealth to all Tunisians: synthesis development policy review. World Bank Group, Washington

World Bank (2014b) A financial sector in disarray. In: The unfinished revolution: bringing opportunity, good jobs and greater wealth to all Tunisians. World Bank Group, Washington. http://pubdocs.worldbank.org/en/336481500382427030/theunfinished-revolution-eng-chap6.pdf

\section{Publisher's Note}

Springer Nature remains neutral with regard to jurisdictional claims in published maps and institutional affiliations. 